\title{
REKONSTRUKSI JABATAN WAKIL PRESIDEN DALAM KETATANEGARAAN DI INDONESIA (TINJAUAN PERBANDINGAN HUKUM NEGARA AMERIKA SERIKAT, CINA DAN FILIPINA)
}

\author{
Oleh : Dewi Mulyanti, SH., M.H.")
}

\begin{abstract}
The 1945 Constitution as a constitution in its development has experienced various patterns and problems that have an impact on the Indonesian state administration system. The constitutional system of the Republic of Indonesia has undergone a reconstruction which has resulted in fundamental changes to the structure and authority of state institutions. Some of the existing state administration system in Indonesia is the Indonesian state administration system based on the preamendment 1945 Constitution, the Indonesian constitutional system based on the constitution of RIS, the Indonesian state administration system based on UUDS 1950 and the Indonesian state administration system based on the 1945 Constitution post amendment.

One of the purposes of the 1945 amendment is to set up checks and balances between state institutions. The relationship is arranged in such a way that there is no concentration of power in one of the state institutions. The concrete form of the 1945 amendment is the substantial distinction of state institutions, particularly in terms of the status, duties, authorities, working relationships and workings of the institutions concerned, including the duties and authorities of the vice-president.

The duties and authorities of the Vice President of the Republic of Indonesia are not expressly regulated in the Constitution although until now there has been a Fourth Amendment to the 1945 Constitution, it is only stipulated in one article that is Article 4 Paragraph (2) of the 1945 Constitution "In performing its duties the President is assisted by one person Vice President. Arrangement of duties and authorities between the President and Vice President of the Republic of Indonesia should be regulated in the Constitution.

In countries with a presidential government system, the Vice President has the duty and authority of the Deputy Head of Government and Deputy Head of State. Serves as a member of one of the parliamentary councils for a country that embraces a two-room system or as a member of a government cabinet under the President.

The Vice Presidential duties set forth in each country's constitution are based on a system of government adopted by each country such as a presidential government system held by the United States and the Philippines or a system of parliamentary government held by China as well as a joint system of government as embraced by Iraq and Uganda. Also influenced by the state form adopted by each country, both union states such as the United States and India as well as unitary states such as the Philippines, Cyprus, China, South Africa, Bulgaria, Iraq and Uganda.

Regarding the authority that is owned by all Vice President in each country, namely as a substitute of president with certain condition as regulated in constitution of each country.

Keywords: President Of Vice President, Constitution in Indonesia
\end{abstract}

*Dosen Tetap Fakultas Hukum Universitas Galuh 


\section{Abstrak}

UUD 1945 sebagai konstitusi dalam perkembangannya telah mengalami berbagai corak dan permasalahan yang berdampak pada sistem ketatanegaraan Indonesia. Sistem ketatanegaraan Republik Indonesia telah mengalami rekonstruksi yang mengakibatkan perubahan fundamental terhadap stuktur dan kewenangan lembaga negara. Beberapa sistem ketatanegaraan yang pernah berlaku di Indonesia yaitu Sistem ketatanegaraan Indonesia berdasarkan UUD 1945 pra-amandemen, Sistem ketatanegaraan Indonesia berdasarkan konstitusi RIS, Sistem ketatanegaraan Indonesia berdasarkan UUDS 1950 dan Sistem ketatanegaraan Indonesia berdasarkan UUD 1945 pasca amandemen.

Salah satu tujuan amandemen UUD 1945 adalah menata keseimbangan (check and balances) antar lembaga negara. Hubungan tersebut ditata sedemikian rupa agar tidak terjadi pemusatan kekuasaan pada salah satu institusi negara. Bentuk nyata dari amandemen UUD 1945 adalah perbedaan yang subtansial tentang kelembagaan negara, terutama dalam hal kedudukan, tugas, wewenang, hubungan kerja, dan cara kerja lembaga-lembaga yang bersangkutan termasuk di dalamnya tugas dan kewenangan wakil presiden.

Tugas dan kewenangan Wakil Presiden Republik Indonesia tidak diatur secara tegas dalam konstitusi walaupun sampai saat ini telah dilakukan perubahan Keempat terhadap UUD 1945, hanya diatur dalam satu pasal saja yakni Pasal 4 ayat (2) UUD 1945 bahwa "Dalam melakukan kewajibannya Presiden dibantu oleh satu orang Wakil Presiden. Pengaturan tugas dan wewenang antara Presiden dan Wakil Presiden Republik Indonesia seharusnya diatur dalam konstitusi.

Pada negara - negara yang menganut sistem pemerintahan presidensial, Wakil Presiden memiliki tugas dan kewenangan sebagai Wakil Kepala Pemerintahan dan Wakil Kepala Negara. Menjabat sebagai anggota salah satu dewan dalam parlemen bagi negara yang menganut sistem dua kamar ataupun sebagai anggota kabinet pemerintahan di bawah Presiden.

Tugas Wakil Presiden yang diatur dalam masing - masing konstitusi negara tersebut didasarkan pada sistem pemerintahan yang dianut oleh masing- masing negara seperti sistem pemerintahan presidensial yang dianut oleh Amerika Serikat dan Filipina atau sistem pemerintahan parlementer yang dianut oleh Cina maupun sistem pemerintahan gabungan seperti dianut oleh Irak dan Uganda. Dipengaruhi pula oleh bentuk negara yang dianut oleh masing - masing negara tersebut, baik negara serikat seperti Amerika Serikat dan India maupun negara kesatuan seperti Filipina, Siprus, Cina, Afrika Selatan, Bulgaria, Irak serta Uganda.

Mengenai kewenangan yang dimiliki semua Wakil Presiden pada masing masing negara, yakni sebagai pengganti presiden dengan kondisi tertentu sebagaimana diatur pada konstitusi masing- masing negara.

Kata Kunci: Jabatan Wakil Presiden, Ketatanegaraan Di Indonesia

\section{Pendahuluan}

Dimulai pada Tahun 2004, rakyat Indonesia memilih langsung Presiden dan Wakil Presidennya, berbeda dengan sebelumnya saat rakyat memilih anggota 
DPR dan selanjutnya para wakil rakyat ini sebagai bagian dari MPR memilih Presiden dan Wakil Presiden sebagai amanat rakyat.

Perubahan sistem pemilihan perwakilan menjadi sistem pemilihan langsung merupakan suatu rekonstruksi hukum bagi ketatanegaraan di Indonesia. Di satu sisi rakyat secara langsung diberikan kekuasaan menentukan pemimpinnya, di sisi lain timbul suatu kesenjangan kaitannya antara pemilihan rakyat secara langsung dengan kewenangan pejabat yang dipilinnya.

Secara sistematik perubahan Undang-Undang Dasar Negara Republik Indonesia Tahun 1945 mengatur pemilihan presiden dan wakil presiden. Pemilihan langsung Presiden dan Wakil Presiden mensyaratkan kesejajaran kualifikasi antara Presiden dan Wakil Presiden, namun pada saat menjabat terdapat kesenjangan tugas dan kewenangan antara Presiden dan Wakil Presiden.

Kekuasaan dan kewenangan presiden secara luas diatur dalam konstitusi, sedangkan wakil presiden umumnya ditentukan oleh Presiden, sehingga tampak tidak memilikinya kewenangan wakil presiden mewujudkan kedaulatan dari pemilihnya. Secara faktual kemenangan calon presiden dipengaruhi suara yang berhasil diperolehnya, bahkan seringkali calon wakil presiden memiliki power lebih besar dari calon presiden.

Posisi wakil presiden pada hakikatnya bukan posisi cadangan, yakni posisi pilihan apabila posisi pertama tidak berwujud. Menjelang pertarungan perolehan kekuasaan dalam Pemilihan Umum Presiden dan Wakil Presiden, banyak bakal calon presiden yang siap mengambil posisi wakil presiden usai mengukur keterpilihan dirinya dibandingkan bakal calon lain. Berbagai macam profesi bermunculan menganggap dirinya pantas menjadi Presiden Indonesia, tetapi segera putar haluan bersedia menjadi bakal calon wakil presiden dan mendekati bakal calon yang dianggap memiliki tingkat keterpilihan (electability) tinggi. Mudahnya beralih pencalonan sebagai bakal calon presiden menjadi bakal calon wakil presiden hanya untuk menduduki jabatan. Hal mana dilakukan mengingat tingkat kemungkinan terpilih menjadi presiden. Posisi wakil presiden merupakan posisi strategis setelah presiden, bahkan dalam kondisi tertentu posisi wakil presiden lebih operasional daripada posisi presiden.

Wakil presiden merupakan jabatan yang ditemukan pada negara yang berbentuk republik (Mochamad Isnaeni Ramdhan, 2015: 3). Demikian juga 
dengan negara Indonesia yang menganut bentuk pemerintahan republik ditemukan beberapa ketentuan yang menyebutkan jabatan wakil presiden dalam konstitusinya. Berikut pasal - pasal yang dimaksud :

1. Pasal 4 ayat (2) Undang Undang Dasar Republik Indonesia Tahun 1945, bahwa Presiden dalam melakukan kewajibannya dibantu oleh satu orang Wakil Presiden;

2. Pasal 6A ayat (1) perubahan ketiga Undang Undang Dasar Republik Indonesia Tahun 1945: seperti halnya Presiden, Wakil Presiden dipilih dalam satu pasangan secara langsung oleh rakyat;

3. Pasal 7 Perubahan Pertama Undang Undang Dasar Republik Indonesia Tahun 1945, masa jabatan dan periodisasi yang sama antara kedua pejabat tersebut, yakni lima tahun dan sesudahnya dapat dipilih kembali untuk satu kali masa jabatan;

4. Pasal 9 ayat (1) Perubahan Pertama Undang Undang Dasar Republik Indonesia Tahun 1945, sumpah atau janji jabatan yang dirumuskan dalam redaksi yang sama antara Presiden dan Wakil Presiden;

5. Wakil Presiden Republik Indonesia menggantikan Presiden jika Presiden mangkat, berhenti, diberhentikan atau tidak dapat melakukan kewajibannya dalam masa jabatannya sebagaimana diatur dalam Pasal 8 ayat (1) Perubahan ketiga Undang Undang Dasar Republik Indonesia Tahun 1945;

6. Presiden Republik Indonesia dan/atau Wakil Presiden Republik Indonesia hanya dapat diberhentikan oleh Majelis Permusyawaratan Rakyat (MPR) dalam masa jabatannya menurut Undang - Undang Dasar sebagimana diatur pada Pasal 3 ayat (3) Perubahan Ketiga Undang Undang Dasar Republik Indonesia Tahun 1945.

Pasal mengenai cara pemberhentian presiden dan/atau wakil presiden ini tidak konsisten dengan cara pengisian presiden dan/atau wakil presiden melalui pemilihan langsung oleh rakyat. Pengisian jabatan presiden dan/atau wakil presiden dilakukan dengan demokrasi langsung, sedangkan pemberhentiannya dilakukan dengan demokrasi keterwakilan. Tidak terdapat penjelasan sistematik beralihnya sistem demokrasi langsung kepada demokrasi perwakilan merupakan salah satu cacat sistematik Perubahan Undang-Undang Dasar 1945. 
Wakil Presiden sebagai jabatan konstitusional seharusnya diatur dalam konstitusi tugas dan kewenangan Wakil Presiden, pertanggungjawaban, serta hubungannya dengan pejabat-pejabat negara yang lain. Jabatan Wakil Presiden Republik Indonesia tidak didukung oleh ketentuan konstitusional. Bahkan terdapat "kekosongan hukum" (rechts-vacuum) terkait jabatan Wakil Presiden, antara lain tugas dan kewenangannya, hubungan kekuasaan antar Wakil Presiden dengan Presiden dan dengan lembaga negara lainnya, serta cara pertanggungjawaban Wakil Presiden. Cara pertanggungjawaban terkait dengan tugas Wakil Presiden saat menjalankan tugas, baik pada saat Presiden berhalangan maupun saat Presiden tidak berhalangan.

Salah satu hal yang menarik untuk dikaji secara yuridis perbedaan mendasar dalam tugas dan wewenang serta hubungan kerja antara Presiden dengan Wakil Presiden dan sebagai bahan perbandingan untuk rekonstruksi ketatanegaraan di Indonesia maka dilihat pula tugas dan wewenang Wakil Presiden di berbagai negara, yang dibatasi pada hal sebagai berikut :

1. Bagaimana tanggung jawab Wakil Presiden dalam sistem ketatanegaraan di Indonesia?

2. Bagaimana tugas dan wewenang Wakil Presiden dalam sistem ketatanegaraan di negara Amerika Serikat, Cina dan Filipina ?

\section{Pembahasan}

\section{a. Rekonstruksi Ketatanegaraan di Indonesia}

Sebelum membahas mengenai sistem ketatanegaraan di Indonesia terlebih dahulu memberikan pengertian mengenai rekonstruksi.

Rekonstruksi adalah pengembalian seperti semula, penyusunan kembali (Kamus Besar Bahasa Indonesia, 1995 : 829). Menurut B. N Marbun bahwa rekonstruksi adalah pengembalian sesuatu ketempatnya yang semula, penyusunan atau penggambaran kembali dari bahan-bahan yang ada dan disusun kembali sebagaimana adanya atau kejadian semula (B.N. Marbun, 1996 : 469). Sedangkan menurut James P. Chaplin menyatakan Reconstruction merupakan penafsiran data psikoanalitis sedemikian rupa, untuk menjelaskan perkembangan pribadi yang telah terjadi, beserta makna materinya yang sekarang ada bagi individu yang bersangkutan (James P. Chaplin, 1997 : 421). 
Terhadap ketatanegaraan di Indonesia bahwa Negara Indonesia merupakan negara hukum. Salah satu ciri Negara hukum, yang dalam bahasa Inggris disebut the rule of law atau dalam bahasa Belanda dan Jerman disebut rechtstaat adalah pembatasan kekuasaan dalam penyelenggaraan negara. Pembatasan itu dilakukan dengan hukum yang kemudian menjadi ide dasar paham konstitusionalisme atau constitutional state, yaitu negara yang dibatasi oleh konstitusi. Dalam konsteks yang sama, gagasan negara demokrasi atau sering disebut pula dengan istilah constituional democracy dihubungkan dengan pengertian negara demokrasi yang berdasar atas hukum (Jimly Asshidiqie, $2006:$ 11).

Setiap negara yang menganut negara hukum, secara umum berlaku beberapa prinsip. Prinsip-prinsip tersebut adalah supremasi hukum (supremacy of law), kesetaraan di hadapan hukum (equality before the law), dan penegakan hukum dengan cara tidak bertentangan dengan hukum (due process of law) (Munir Fuady, 1985 : 218).

Adanya rekonstruksi ketatanegaraan di Indonesia dimulai sejak Indonesia memproklamirkan dirinya sebagai negara yang merdeka. Sebagai negara hukum, Indonesia meletakkan Undang Undang Dasar Republik Indonesia Tahun 1945 sebagai konstitusi penyelenggaraan negara (UndangUndang Dasar Negara Republik Indonesia 1945 Pasal 1 ayat (3)). Bahwa perlunya pembatasan kekuasaan (the limited state), agar penyelenggaraan Negara tidak bersifat sewenang-wenang. Dimana Undang Undang Dasar Republik Indonesia Tahun 1945 dianggap sebagai Institusi yang paling efektif untuk melindungi warga negarannya melalui konsep Rule of law atau Rechtstaat.

Menurut Andrew Heywood (Miriam Budiardjo, 2008: 171) konstitusionalisme merupakan perangkat nilai dan aspirasi politik yang mencerminkan adanya keinginan untuk melindungi kebebasan dan melakukan pengawasan (check) internal maupun eksternal terhadap kekuasaan pemerintah atau dengan kata lain merupakan norma pokok (grundnom) yang merupakan sumber utama tertib hukum di Indonesia (hierarki perundangundangan).

Undang Undang Dasar Republik Indonesia Tahun 1945 sebagai konstitusi dalam perkembangannya telah mengalami berbagai corak dan 
permasalahan yang berdampak pada sistem ketatanegaraan Indonesia. Sistem ketatanegaraan Republik Indonesia telah mengalami pergeseran yang mengakibatkan perubahan fundamental terhadap stuktur dan kewenangan lembaga negara.

Berikut ini sistem ketatanegaraan yang pernah berlaku di Indonesia (Chairul Anwar, 1999 : 71-77) :

1. Sistem ketatanegaraan Indonesia berdasarkan Undang Undang Dasar Republik Indonesia Tahun 1945 pra-amandemen;

2. Sistem ketatanegaraan Indonesia berdasarkan konstitusi RIS;

3. Sistem ketatanegaraan Indonesia berdasarkan UUDS 1950;

4. Sistem ketatanegaraan Indonesia berdasarkan Undang Undang Dasar Republik Indonesia Tahun 1945 pasca amandemen.

Salah satu tujuan amandemen Undang Undang Dasar Republik Indonesia Tahun 1945 adalah menata keseimbangan (check and balances) antar lembaga negara. Hubungan tersebut ditata sedemikian rupa agar tidak terjadi pemusatan kekuasaan pada salah satu institusi negara. Bentuk nyata dari amandemen Undang Undang Dasar Republik Indonesia Tahun 1945 adalah perbedaan yang subtansial tentang kelembagaan negara, terutama dalam hal kedudukan, tugas, wewenang, hubungan kerja, dan cara kerja lembaga-lembaga yang bersangkutan termasuk di dalamnya tugas dan kewenangan wakil presiden.

\section{b. Tanggung Jawab Wakil Presiden Dalam Sistem Ketatanegaraan Di Indonesia}

Tugas dan kewenangan Wakil Presiden Republik Indonesia tidak diatur secara tegas dalam konstitusi walaupun sampai saat ini telah dilakukan perubahan Keempat terhadap Undang Undang Dasar Republik Indonesia Tahun 1945, hanya diatur dalam satu pasal saja yakni Pasal 4 ayat (2) Undang Undang Dasar Republik Indonesia Tahun 1945 bahwa "Dalam melakukan kewajibannya Presiden dibantu oleh satu orang Wakil Presiden.

Tugas dan wewenang Wakil Presiden dapat diberikan dalam ranah kekuasaan eksekutif riil sebagai wakil kepala pemerintahan maupun dalam ranah kekuasaan eksekutif nominal sebagai wakil kepala negara. 
Berbeda dengan pertanggungjawaban pembantu Presiden yang lain, seperti Menteri Negara yang harus mempertangggungwajabkan tugasnya kepada Presiden sesuai dengan substansi Pasal 17 ayat (3) Undang Undang Dasar Republik Indonesia Tahun 1945.

Wakil Presiden tidak bertanggung jawab kepada Presiden karena Wakil Presiden tidak dipilih dan diangkat oleh Presiden melainkan oleh rakyat. Dikaitkan dengan Pasal 6A ayat (1) Perubahan Ketiga Undang Undang Dasar Republik Indonesia Tahun 1945 yang menyatakan dengan tegas Presiden dan Wakil Presiden dipilih oleh rakyat. Tidak ada pasal dalam Undang Undang Dasar Republik Indonesia Tahun 1945 dan perubahannya yang mengatur pertanggungjawaban Wakil Presiden, baik sebagai Wakil Kepala Pemerintahan maupun sebagai Wakil Kepala Negara.

Konsekuensi logis dari ketentuan ini bahwa yang dipilih mengemban kewajiban pertanggungjawaban kepada yang memilih, sebaliknya yang memilih memiliki kewenangan meminta pertanggungjawaban kepada yang dipilih. Pertanggungjawaban wakil presiden juga dipengaruhi oleh faktor pencalonan dan pemilihan presiden dan wakil presiden yang dilakukan dengan sistem paket, baik keduanya berasal dari partai politik yang sama, maupun keduanya berasal dari partai politik yang berbeda (Harun Alrasid, 1999:51).

\section{c. Tugas Dan Wewenang Wakil Presiden dalam Sistem Ketatanegaraan di Negara Amerika Serikat, Cina dan Filipina}

Wakil Presiden senantiasa ditemukan pada konstitusi negara- negara yang menganut bentuk pemerintahan Republik dengan sistem pemerintahan presidensial seperti Amerika Serikat, Filipina. Juga negara republik dengan sistem pemerintahan parlementer bagaimana dianut negara Cina.

Tatacara pengisian jabatan, masa jabatan, sumpah jabatan, lembaga pemilih dan lembaga yang menilai pertanggungjawaban antara Presiden dan Wakil Presiden adalah sama sedangkan tugas Wakil Presiden dipengaruhi oleh bentuk negara yang dianut oleh masing-masing negara ;

1. Tugas yang diberikan kepada Wakil Presiden Amerika Serikat dan Filipina sebagai Ketua Senat bukan anggota;

2. Tugas yang diberikan kepada Wakil Presiden Filipina sebagai anggota kabinet; dan 
3. Tugas yang diberikan kepada Wakil Presiden Cina sebagai pelaksana sebagian tugas dan kekuasaan Presiden setelah ditentukan oleh Presiden.

Tugas Wakil Presiden yang diatur dalam masing-masing konstitusi negara tersebut didasarkan pada sistem pemerintahan yang dianut oleh masing- masing negara seperti sistem pemerintahan presidensial yang dianut oleh Amerika Serikat dan Filipina atau sistem pemerintahan parlementer yang dianut oleh Cina maupun sistem pemerintahan gabungan seperti dianut oleh Irak dan Uganda. Dipengaruhi pula oleh bentuk negara yang dianut oleh masing-masing negara tersebut, baik negara serikat seperti Amerika Serikat dan India maupun negara kesatuan seperti Filipina, Siprus, Cina, Afrika Selatan, Bulgaria, Irak serta Uganda.

Mengenai kewenangan yang dimiliki semua Wakil Presiden pada masing-masing negara, yakni sebagai pengganti presiden dengan kondisi tertentu sebagaimana diatur pada konstitusi masing- masing negara.

Pada negara-negara yang menganut sistem pemerintahan presidensial, Wakil Presiden memiliki tugas dan kewenangan sebagai Wakil Kepala Pemerintahan dan Wakil Kepala Negara. Menjabat sebagai anggota salah satu dewan dalam parlemen bagi negara yang menganut sistem dua kamar ataupun sebagai anggota kabinet pemerintahan di bawah Presiden.

Secara konstitusional tugas dan kewenangan Wakil Presiden Amerika Serikat hanya diatur dalam Article One Section Three sebagai berikut : The Vice President of The United States shall be President of the Senate, but shall have no vote, unless they be equally divided ( Wakil Presiden Amerika Serikat harus menjadi ketua senat, tetapi tidak memiliki hak suara, kecuali suara mereka terbagi secara seimbang)

Terkait dengan kewenangan Wakil Presiden Amerika Serikat sebagai pengganti Presiden, berdasarkan amendment 25 Konstitusi Amerika Serikat diatur empat prosedur (John D. Ferick, $1992: 81$ ) antara lain sebagai berikut :

1. Menjadi pejabat presiden saat pemecatan Presiden dari jabatannya atau kematiannya atau mengundurkan diri.

2. Menjadi pejabat presiden saat Presiden secara tertulis menyatakan ketidakmampuannya dalam melaksanakan kekuasaan dan tugastugas kepresidenan. 
3. Menjadi pejabat presiden dan mengajukan calon Wakil Presiden yang harus disahkan oleh Senat dan DPR.

4. Menjadi pejabat presiden saat Wakil Presiden dan beberapa orang menteri atau sebuah dewan sejenis Kongres secara tertulis menyatakan ketidakmampuan Presiden dalam melaksanakan kekuasaan dan tugas kepresidenan.

Sama halnya dengan kewenangan Wakil Presiden Filipina secara konstitusional hanya diatur dalam Article VII Section 3 sebagai berikut : The Vice President may be appointed as a member of the cabinet. Such appointment requires no confirmation ( wakil presiden dapat ditunjuk oleh Presiden sebagai anggota kabinet. Penunjukan ini tidak membutuhkan ijin). Kaitannya dengan kewenangan Wakil Presiden menggantikan Presiden diatur pada Article VII Section 7-11 sebagai berikut :

1. Wakil Presiden Filipina menggantikan Presiden sebagai Presiden jika yang terakhir tidak memenuhi persyaratan yang telah ditentukan;

2. Wakil Presiden Filipina menggantikan Presiden sebagai Presiden, jika pada awal masa jabatannya, Presiden terpilih wafat atau tidak mampu melaksanakan tugasnya selamanya;

3. Wakil Presiden Filipina menggantikan Presiden sebagai Presiden, jika Presiden menyerahkan kepada Ketua Senat dan Ketua DPR pernyataan tertulis tentang ketidakmampuannya melaksanakan kekuasaan dan tugas - tugas kepresidenan, sampai dengan ia mengirimkan pernyataan tertulis yang membatalkannya.

Mengenai tatacara pengisian jabatan Wakil Presiden Republik Rakyat Cina diatur dalam Pasal 79 ayat (1), bahwa: Presiden dan Wakil Presiden Republik Rakyat Cina dipilih oleh Kongres Rakyat Nasional. Berbeda dengan pemilihan Presiden dan Wakil Presiden pada negara Amerika Serikat dan Filipina pemilihan Presiden dan Wakil Presiden Republik Rakyat Cina tidak melibatkan rakyat, melainkan hanya dipilih melalui KRN sebagai lembaga tertinggi. Kekuasaan Wakil Presiden sebagai pendamping Presiden ditentukan oleh Presidennya (S.E Finer, 1996 : 191-200). 


\section{Kesimpulan}

Perubahan sistem pemilihan keterwakilan menjadi sistem pemilihan langsung oleh rakyat merupakan rekonstruksi dalam ketatanegaraan di Indonesia termasuk pemilihan Presiden Dan Wakil Presiden. Konsekuensi yang dipilih mengemban kewajiban pertanggungjawaban kepada yang memilih, sebaliknya yang memilih memiliki kewenangan meminta pertanggungjawaban kepada yang dipilih.

Tugas dan wewenang presiden telah diatur dalam konstitusi negara kita, tetapi tugas dan kewenangan Wakil Presiden Republik Indonesia tidak diatur secara tegas dalam konstitusi walaupun sampai saat ini telah dilakukan perubahan Keempat terhadap Undang Undang Dasar Republik Indonesia Tahun 1945, hanya diatur dalam satu pasal saja yakni Pasal 4 ayat (2) Undang Undang Dasar Republik Indonesia Tahun 1945 bahwa "Dalam melakukan kewajibannya Presiden dibantu oleh satu orang Wakil Presiden.

Sama halnya negara-negara yang memiliki sistem pemerintahan yang sama seperti Amerika Serikat dan Filipina dan sistem pemerintahan parlementer seperti Cina, bahwa tugas wakil presiden tidak banyak diatur dalam konstitusinya. Secara konstitusional tugas dan kewenangan Wakil Presiden Amerika Serikat hanya diatur dalam Article One Section Three bahwa Wakil Presiden Amerika Serikat harus menjadi ketua senat, tetapi tidak memiliki hak suara, kecuali suara mereka terbagi secara seimbang, kekuasaan Wakil Presiden di negara Republik Rakyat Cina sebagai pendamping Presiden ditentukan oleh Presidennya dan sama halnya dengan kewenangan Wakil Presiden Filipina secara konstitusional hanya diatur dalam Article VII Section 3 bahwa wakil presiden dapat ditunjuk oleh Presiden sebagai anggota kabinet dan penunjukan ini tidak membutuhkan ijin.

Lemahnya pengaturan tugas dan wewenang wakil presiden dalam konstitusi negara masing - masing mengesankan bahwa wakil presiden tidak memiliki tugas pokok.

\section{Daftar Pustaka}

Alrasid. Harun, 1999, Pengisian Jabatan Presiden, Jakarta, Grafiti.

Anwar, Chairul, 1999, Konstitusi dan Kelembagaan Negara, Jakarta, CV. Novindo Pustaka Mandiri. 
Asshidiqie. Jimly, 2006, Pengantar IImu Hukum Tata Negara Jilid II, Jakarta, Sekretariat Jenderal dan Kepaniteraan Mahkamah Konstitusi.

Budiardjo. Miriam dkk, 2008, Dasar-Dasar IImu Politik, Jakarta, Gramedia Pustaka Utama.

Chaplin. James P, 1997, Kamus Lengkap Psikologi, Jakarta, Raja Grafindo Persada.

Ferick. John D, 1992, The Twenty-Fifth Amendment its Complete History and Applications, New York, Fordham University Press.

Finer. S.E, 1996, Comparing Constitutions, Oxford, Claredon Press.

Fuady. Munir, 1985, Teori Negara Hukum (Rechstaat), Bandung, Regika Aditama.

Marbun. B.N, 1996, Kamus Politik, Jakarta, Pustaka Sinar Harapan.

Tim Penyusun, 1995, Kamus Besar Bahasa Indonesia, Jakarta, Balai Pustaka.

\section{Perundang-undangan}

Undang Undang Dasar Republik Indonesia Tahun 1945 